\title{
Chapter 1 \\ Real Estate and the Legal System of Japan
}

\author{
Hideo Fukui
}

\begin{abstract}
In Part I, entitled Real Estate and the Legal System, we analyze ownerunknown land issues, land acquisitions, and real estate auctions.

The use and value of real estate such as land and buildings are significantly affected by public laws and regulations related to urban planning and construction, the environment, and taxation; for example, contract laws such as the Act on Land and Building Leases; private laws regulating torts, collateral enforcement, and so on; tax laws that regulate transfer taxes, ownership taxes, and transaction taxes; and regulations surrounding land use and urban infrastructure development. This paper discusses, therefore, the relationships between these laws and real estate, identifies problems in the laws associated with real estate in Japan, and proposes improvements.
\end{abstract}

First, in recent years, owner-unknown land issues have become a serious concern in Japan. The Japanese registry does not always reflect the actual rightful owner, primarily because such registration is only a perfection requirement in civil law and registration involves a great deal of time and money. For example, because a large extent of land is registered to owners from nearly 100 years ago, it has changed hands many times through inheritance, which means that today, it is extremely difficult to determine the actual owner (inheritor) without spending a great deal of time and money. However, if the profits to be obtained from the land do not justify such expense, the land remains unused as "owner-unknown land."

Buying and selling land under Japanese civil law requires an agreement from all landowners including in the case of shared ownerships; therefore, even if the land has high returns, if it is "owner-unknown land," it cannot be used effectively. With a focus on unknown-owner land, in this section, four writers provide multifaceted perspectives on the causes thereof, the defects in the current system, and the possible solutions.

Eminent domain, the system which allows the acquisition of land against the land owner's will for public projects, is widely institutionalized in many countries. It

\footnotetext{
H. Fukui ( $\triangle)$

National Graduate Institute for Policy Studies, Minato-ku, Tokyo, Japan

e-mail: fukui@grips.ac.jp

Y. Asami et al. (eds.), Frontiers of Real Estate Science in Japan, New Frontiers in

Regional Science: Asian Perspectives 29,

https://doi.org/10.1007/978-981-15-8848-8_1
} 
works to mitigate the owner-unknown land issues as far as lands are acquired by public projects.

Further, real estate auctions are often held when liens are placed on land and/or residences for housing loan defaults. The Japanese civil auction system, which was institutionalized at the end of the nineteenth century, stipulates that a tenancy that is behind on a mortgage may resist a purchase unconditionally as long as the mortgage default period is within 3 years (short-term lease protection system/former Civil Code Article 395). This system was intended to avoid the unstable use of mortgaged properties and to promote the effective use of real estate; however, because the majority of users and the beneficiaries of this system were in fact anti-social groups, it was used to demand money unjustly from debtors and buyers, thus preventing the effective use of the mortgaged properties.

When the protection of short-term leases was abolished in 2004, these types of interferences are said to have decreased drastically. However, successful bids for auctioned real estate properties continue to be lower than in general transactions. Therefore, here, we provide a quantitative analysis of these situations and propose further auction system improvements.

Below, we introduce the outlines of each theory in Part I.

Keywords Owner-unknown land · Land acquisition · Real estate auction · Ownership · Inheritance $\cdot$ Registry

\subsection{Iwasaki (2020)}

This paper describes how and why owner-unknown lands have been increasing in Japan's shrinking population and proposes some ideas on the solution to the relating legal issues. Even for land with economic value, there is no great sense of need to register the name and address of the owner when that land is used for an intended purpose or for revenue, and even through there may be an occupant, the true owner may be unknown. In this case, it is possible to consider measures to resolve the problem caused by the owner being unknown through tax procedures and collection procedures. For land that has lost its economic value, however, the only way to transfer the control to the government or a public organization is to establish new forcible execution measures under administrative law. And in parallel with such compulsory measures, there should be measures to proactively promote the donation of land, needed for transport, disaster prevention, and public use, that is of public interest to the government of public organizations. 


\subsection{Nakagawa (2020)}

The problem of land with unknown ownership is becoming increasingly evident. This paper examines the need for the titling system using perspectives from economics and considers what sorts of titling system works for which types of society.

A series of previous researches categorize the titling systems used in many advanced countries as either registration systems or recording systems. Japan's titling system is categorized as a recording system. However, since the details of registered information are confirmed through various registration procedures, the system also has aspects that resemble a registration system. This can be interpreted as having selected the titling system's strength that considerably lowers the level of litigation risk. In that case, transaction costs become very high.

The result of selecting the recording system in Japan, which is a system with a very high strength, could explain why nobody takes insurance to cover the risk of title litigation.

In Japan, it is highly likely that the unreversible population decline, low birth rate and aging population will lower the profitability of land. In that case, a titling system with low strength is likely to be the best for society as indicated in the analysis above.

\subsection{Fukui (2020)}

The increase of land plots with unknown owners, that is, land plots whose owner's name and address are not easily identifiable through repeated inheritance, etc., emerges as an imminent social issue.

The big reason for this phenomenon is the civil code which unconditionally allows sharing of real estate by unlimited number of joint owners, for one thing, and the registration system of real estate which does not require the true owner to register and thus does not show real rights of real estate, for another.

To reduce the increase of land plots with unknown owners as a proactive measure and to utilize them as a reactive measure, it is necessary to set up the one-owner principle with the ban of the sharing of real estate even through inheritance, to abolish fixed asset tax on buildings and houses, to require the new owner of real estate to register the right upon the transfer of ownership and for the registration office to make it public, to amend the Land Expropriation Act to facilitate the purchase of the land plots for public purpose without the owner identification, to create the institutional arrangement which allows to fictionally replace the will of the owner, to amend the civil code to allow the disposal of shared real estate by the majority of the joint owners. 


\subsection{Yoshihara (2020)}

In recent years, because of the time needed to identify landowners, there have been several cases in Japan that have interfered with measures to recover from disasters, to eliminate abandoned farmlands, and to prevent vacant houses. The authors focused on property tax in basic municipalities to quantitatively understand this situation, conducting a questionnaire survey with the tax bureaus in all municipalities and Tokyo Prefecture (23 wards). By examining the seriousness of the problems caused by unregistered inheritance, which is a major factor causing "unknown owners," on the practice of property tax, we aimed to indirectly understand the problem of "unknown owners." The social and systematic factors behind this issue are summarized in this paper based on the survey results (responses from 888 municipalities in Japan: recovery rate of 52\%), concluding that as long as the system remains as is, this problem will inevitably grow as the population declines. Therefore, it is recommended that measures be urgently introduced to promote timely inheritance registrations, the preparation of "receptacles" for land having no use plans, and the preparation of a land information infrastructure.

\subsection{Ohya (2020)}

This study examines the negative factors in the designing legal system that lead to "administration failure" that impedes the social welfare related to the grant and approval of the business project from the case of land acquisition in Malaysia in ASEAN countries. Malaysia has introduced a land acquisition system for profitoriented enterprises since 1991 with the aim of economic growth to reduce poverty and secure resources for income redistribution. The author theoretically analyzes the negative impacts on the implementation of economic policy when the operation of land acquisition for profit-oriented enterprises and bribery are linked and what kind of factors it depends on in the legal system design. In conclusion, the author extracts three common negative effect factors in the design of legal system related to the grant and approval of the administration that impair social welfare. First, the provision of the constitution within the limits of the law increases the degree of freedom of legislation and gives the administration broad discretion (flexible discretion). Second, for administration to have wide discretion, the administration can make decisions that have a negative effect on the accomplishment of the policy goals and decisions that undermine the public's credibility. Third, such administrative decisions that have a negative effect on the fulfillment of policy goals are elicited through bribery that seeks to exploit administrative authority having broad discretion. These factors impede the role that the administration should play in order to maximize social welfare by bribery to an administration that has the authority to grant and approve business. 


\subsection{Ooka (2020)}

This paper shows the effect of a series of system revisions of judicial real estate auction in the 2000s on three factors; bid acceptance ratio, number of bidders, and highest bid.

For some time, it is said that the sale price by the judicial real estate auction was always low in comparison with general real estate trading because of the institutional defect of judicial real estate auction system. The correction of difference of the sale price brings profit to the creditor and the debtor, as well as, it may be said that it is the important policy problem that can be connected for the activation of the real estate finance market by drop of the lending rate through the improvement of the collateral property value.

He conducted empirical analysis using multi-year data of judicial real estate auction and general real estate trading. I clarified that bid acceptance ratio, number of bidders, and highest bid were improved considerably by a series of system revision of judicial real estate auction; on the other hand, the price differences between judicial real estate auction and general real estate trading was far more than $30 \%$. In addition, based on these analysis results, I consider that the problem to be left in the current system of judicial real estate auction bringing about the price difference, and suggest about necessity of further system revisions.

Open Access This chapter is licensed under the terms of the Creative Commons Attribution 4.0 International License (http://creativecommons.org/licenses/by/4.0/), which permits use, sharing, adaptation, distribution and reproduction in any medium or format, as long as you give appropriate credit to the original author(s) and the source, provide a link to the Creative Commons licence and indicate if changes were made.

The images or other third party material in this chapter are included in the chapter's Creative Commons licence, unless indicated otherwise in a credit line to the material. If material is not included in the chapter's Creative Commons licence and your intended use is not permitted by statutory regulation or exceeds the permitted use, you will need to obtain permission directly from the copyright holder.

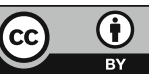

